\title{
PATHS OF SALT AND ARTISTIC INTERACTIONS WITH CACELA VELHA: TWO PUBLIC ART PROJECTS SUSTAINED BY AN INTEGRATED VIEW OF PLACE THROUGH PARTICIPATORY DESIGN
}

\author{
Paula Reaes Pinto \\ Professor at the Department of Visual Arts and Design- University of Évora, CIAUD researcher at \\ the School of Architecture - University of Lisbon, Portugal, paulareaespinto@gmail.com
}

\begin{abstract}
This paper addresses the concept of an integrated perspective of place through participatory design in public art, namely in the development of the artistic projects Paths of Salt and Artistic Interactions with Cacela Velha. It begins with the explanation of the guiding concepts of the research and methodologies, such as place, emphatic and participatory approaches, alluding to the active investigation; and finishes with a detailed description of both projects and the analysis of their results.
\end{abstract}

Keywords: Participatory Design, Integrated Perspective of Place, Public Art, Labour Activities, Natural Resources.

\section{INTRODUCTION}

The art projects I want to present here - Paths of Salt and Artisitic Interactions with Cacela Velha - were based on two case studies that were part of practical research for my $\mathrm{PhD}$ thesis. Artistic Interactions with Cacela Velha was monitored by the researcher. Both projects resulted from proposals presented to the municipalities of Castro Marim and Vila Real de Santo António in the years of 2001 and 2007, respectively. They included various art productions. The first was exhibited in 2003 in Castro Marim, the latter in 2009 in Cacela Velha (Reaes Pinto, 2013).

This investigation reframes a consideration of place organized around labour as the core concept. So, the human, geophysical, historic, social, economic, ecological and cultural aspects of place are observed primarily as they relate to work or labour in that place. Therefore, the artistic practice developed in the investigation can be a contribution for knowledge, insofar the investigation focuses on questions that expand the notion of place for artists and designers, filtered through the lenses of manual labour as a human physical relation between people and earth or sea (Fig.1).

The projects were materialized in places, which are strongly characterized by the relationships between the physical subsistence of their residents and the local natural resources. Therefore, these kind of lives are marginalized by the logic of hegemonic globalization. 


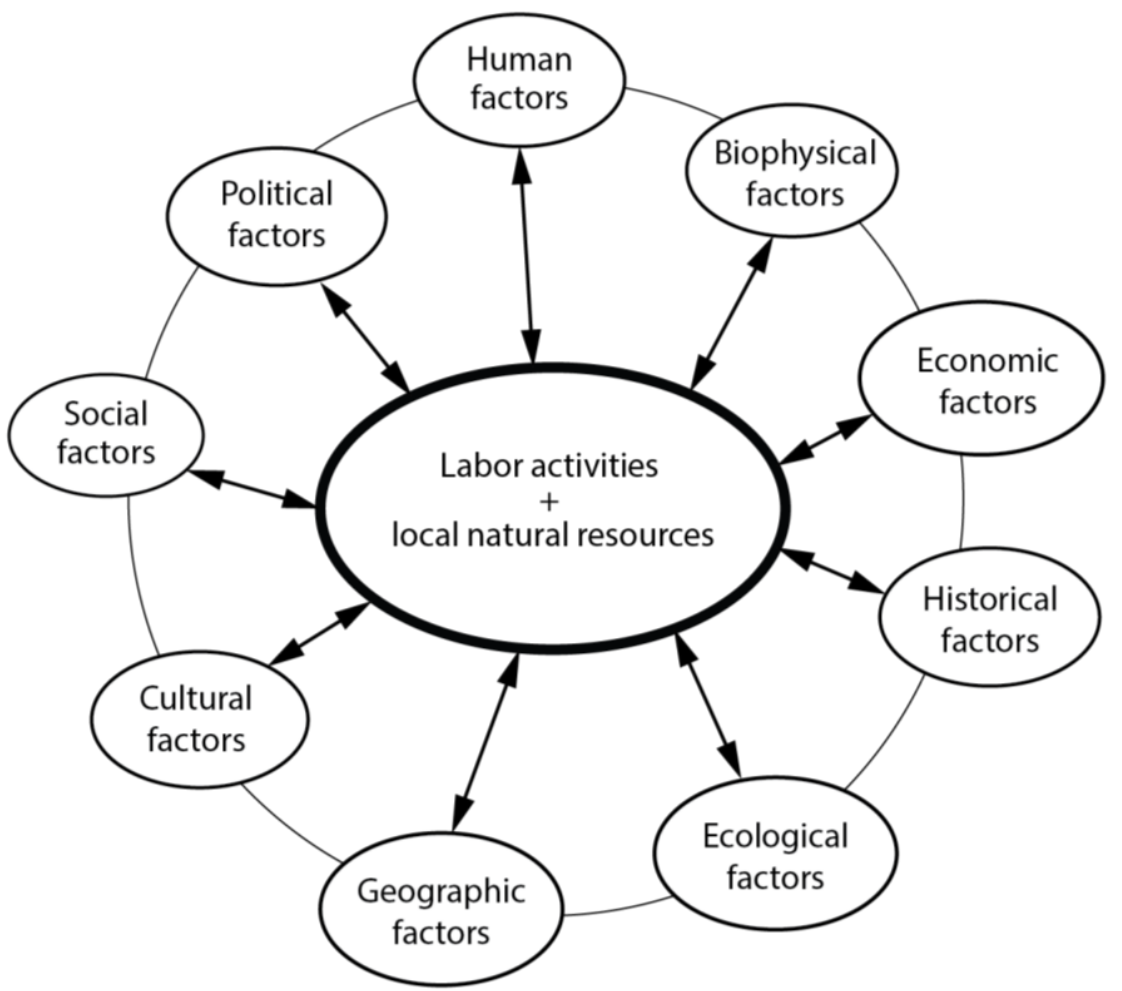

Fig. 1: Integrated place (Reaes Pinto, 2013).

\section{OBJECTIVES}

1. To analyse, test and interpret the evidence concerning the importance that place, understood in an integrated way, can have in the conception and materialization of art interventions in hybrid environments, both in urban and rural contexts, worked out with and for local communities and populations;

2. To demonstrate, through participatory design, the relevance of public art involving local populations actively;

3. To test and assess the receptivity of the people participating to the methodological characteristics of the projects;

4. To give public recognition to those involved and show off the value of their labour activities in a dignified form;

5. To encourage local populations to intervene in a more conscious way in the transformation of the places in which they live and work.

\section{CORE CONCEPTS AND METHODOLOGY}

The projects belong to the sphere of public art and centred in participatory design, sustained by an integrated perspective of the place, understood in its complexity - combining human, biophysical, geographical, economic, political, social, cultural, historical and ecological aspects that largely characterize local life experiences.

The notion of place is of particular interest to me because it is a way of learning about the relations that local people establish among themselves and with their environment. According to Cresswell (2004, p.11), a place is more than a simple thing in the world, it is a means of learning about it. The projects focused on the relation between labour activities and local natural resources which are visible in the territory and therefore in the landscape of Castro Marim and Cacela Velha. They explored the everyday salt production, fishing activities and bivalve harvesting in the lagoon near the two villages. This investigation is centred on the living narrative created by local inhabitants in that specific landscape.

The inclusion of 'place' as the main concept in the development of the previously mentioned projects involved not only aesthetic assumptions inherent to any art endeavour, but also matters of ethics. Among 
these are the possible contributions to a public appreciation of neglected traditional labour activities and of their importance as a way to promote these places and the role that these populations have in the construction of their environment.

The present projects are anchored in the concept of place-specific, a designation that was first used in the 1990 s by the art critic Lucy Lippard to define an artistic practice based on experience of space where it is developed, unlike site-specific practices which only consider the visual and physical dimensions of space (architectural, geographical and geometrical) (Lippard 1995, p.54). Thus, in the context of the investigation a place-specific artistic approach was developed, based on various aspects of the place, particularly in the relationship between people and the environment where they live and work and in their own existing social relations. It is assumed as a more comprehensive, integrative and alternative art to the practice of sitespecific.

This place-specific artistic practice in question is rooted in the concept of 'new genre public art' - an expression coined by the artist Suzanne Lacy, in 1995, in the context of her book (and art project) Mapping the terrain: new genre public art. This dimension of public art focused on specific communities valorizing personal narratives instead of universal ones. The artist becomes an actor or facilitator working directly with real people, rather than dealing with an abstract public (Lacy, 1995, p.20).

Analogously, design activism refers to creative practices that engage political, social and environmental agencies (Fuad-Luke, 2009, p.27). Generally, it distinguishes itself from commercial approaches embracing, marginal, or non-profit engaged design theories. Its practitioner "...is a free agent; a non-aligned social broker and a catalyst; a co- creator and a happener" (Fuad-Luke, 2009, p.xxi).

The development of these projects, taking into account the different people who live in Castro Marim and Cacela Velha, as well as the importance of their daily lives and their involvement in the artistic process, results from a respect for the places as a plurality of identities. The multiple identities of a place are produced by the people who utilize it. In the perspective of philosopher Henri Levebvre (1991) such production is related to the life experiences and the meanings assigned to a given place by its users. This idea of space has affinities with the notion of place I used in my work. Thus, the relationship established between each of the inhabitants and the local natural resources through their labour has become the raw material I employed as an artist and researcher.

Also the concept of place that deals in these projects, integrates the notion of anthropological place, in that it can be defined as identity, relational and historical (...) and symbolic (AUGÉ, 1998, pp.83, 87).

Reflecting on the process and results of Paths of Salt, I had the opportunity to redefine some of my initial concepts and ways of approaching local people, in order to develop an art practice closer to them and featuring them. In the case of the second project I believe those who participated were able to speak out through it, through recordings of their live narrative artistic material.

\section{INTERACTIVE PRACTICES BETWEEN ARTIST AND COMMUNITY}

We started this endeavour with the intention of developing projects based on the daily lives of manual labourers of the villages of Castro Marim and Cacela Velha (in Eastern Algarve), that were of interest to the active participation of local people, in particular the level of how they relate to each other, build and transform the place. We used an empathetic approach as a methodology of interaction design, whose aesthetic dates back in paradigm to listen to and talk with the local people. It was explained to them what we wanted to do and they were encouraged to participate in the projects. With regard to the second project Artistic Interactions with Cacela Velha, they were given voice, by means of their life histories, they recounted. The development of the projects was based on the intersubjective vulnerability, since this was only possible to exist with the collaboration of the local inhabitants.

In the context of the projects presented here, what was valued was the non-hierarchical knowledge, anchored in the sharing of the individual experience of each participant in the project, which was built through dialogue, listening to others and by trying to understand them. The predisposition to listen to and, as a consequence, the relational character of the project, has been extended to areas of knowledge extrinsic to art, to be understood in a comprehensive manner and transverse to life itself. In this sense, the attitude of listening to the other was extrapolated, in accordance with the notion of enlightened listening, created by philosopher David Levin (1989, p.223), which relates to a sense of mutual listening, both on the part of the artist and the participants in the project, promoting inter-knowledge between both.

Affinities can also be found with the philosopher Gemma Fiumara (1995, p.19). In his book The Other Side of Language - a Philosophy of Listening, Fiumara criticizes the hegemony of the discourse of rationalist 
western culture, which neutralizes the processes of listening, condemning the Other to silence, advocating the opposing attitude of listening founded on the non-hierarchy of cultures, knowledge, in order to balance the speech.

An approximation to the concept of connected knowing, was also considered, which was a term used, for the first time in the study Women's Ways of Knowing, the authorship of Mary Belenky, Blythe McVicker de Clichy, Nancy Rule Goldberg and Jill Mattuck Tarule, published in 1986. This type of knowledge is built on the basis of the subjective belief that reliable knowledge is the result of personal experience and not on what is imposed by an authority. It is a form of knowledge that is based on the practice of conversation, in which, each one of the participants involved in the dialogue seeks, by means of an empathetic approach, to learn from the wisdom of others. Therefore, once that knowledge is derived from experience, the way to become acquainted with the ideas of others is trying to share the experience that led a person to having a particular idea (Belenky; Clichy; Goldberger; Tarule, 1986, pp.112-113). The people who share connected knowledge learn through empathy, or in other words, through the perspective of another person.

The holistic perspective of physicist David Bohm also constituted an important reference for this study, due to his contribution of finding a way to improve the quality of life of human beings, both at the level of their inter-relations, as well as their relations with the environment. His understanding of the world as a whole, in which all things are inter-related in a dynamic way, was based on the behaviour of subatomic particles. It was found that the electrons are interwoven within their environment, and cannot be separated from their context, which include the observer himself. In this sense, Bohm assigns a prominent role to dialogue as a way to learn to listen to the other, by enjoying the relationship between people and helping to solve social problems (Bohm, 1989, pp. 113-119, 121).

Therefore, the projects were developed with small groups of local population (a group of children and local craftsmen in the first and a group of children and old people in the second) in the process of knowing and doing, according to the participatory design methodology. Their role, initially as participants, switch afterwards, in the quality of observers, to the role of a public, when they came to the art installation premises and were confronted with the objects partially created by them.

\section{THE LANDSCAPE AS PLACE}

According to Cosgrove (apud Andrews, 1999, p.21), the appearance of growing landscape occurs to the extent that the land acquires capital value, becoming itself a commodity that despises the "social meaning" or the personal value, which it had previously, for those to whom the land was a familiar environment. The aesthetic value of the landscape replaces the value of the use and dependence that the earth had until then: this is the "vision of the weird", through which the earth is transformed into landscape.

It is interesting to observe how this perspective is closer to the idea of place that interests me. In both projects I looked at the territory - also considering landscape - as a manifestation of certain ways of living no longer popular and even marginalized, to which the land and sea are crucial natural resources. Such ways of living reflect the daily labour routines of a community or group of people of a given place. As such, these routines are a form of knowledge. The idea of place corresponds to a space with history, memories, meanings and living experiences, understand the landscape while revealing the living experiences of a space - the place.

\section{DESCRIPTION OF THE PROJECTS}

Strongly grounded on experience as a source of knowledge and on the interaction with the place and its inhabitants, the projects required relations of proximity and even intimacy with the local people. Therefore, the research used, at every stage, the methodologies of fieldwork and interactive design, requiring temporary residence. The field work, besides being part of a participatory design methodology, functioned as an art practice and not as a scientific experiment.

In these projects, the people who were my focus of interest only differed in life experiences, with less estranged knowledge from natural resources, and the environment in which they live. The aim was to learn from the experiences of these people, share them, and to build something - the projects entitled Paths of Salt and Artistic Interactions with Cacela Velha, from the dialogue, as a result of the interaction. What was built was not far from these people, nor was the target audience, exclusively, from another public. The projects were carried out, also, for the salt farmers, retired fishermen, women that worked in fishing and harvesting activities and for all the people with whom they interacted, the place where they lived and worked with. 
In relation to the project entitled Artistic Interactions with Cacela Velha, the field work has been expanded to a public presentation of the project, since during this period of time we held interviews and questionnaires with the population in general, who visited the exhibition and to the group of local people who had worked on the project.

The methodology of field work, which has been characterised, briefly, by constant dynamic interactions between the researcher and the local inhabitants, their activities and the places where they work, also has affinities with what is termed as research-action, to the extent that it is a methodology that "makes the actor researcher, and vice-versa, and leads the action for research purposes. Its starting point is particular, since it bases its dynamic on the action, and considers the actors not as passive objects of research, but as participants".

This is a continuous process which influences the entire research and "objects" of knowledge are considered as "subjects" of knowledge (Guerra, 2000, p.53). In short, the peculiarity of action research focuses on intentional interaction between research and action. In this context, "the knowledge is produced in direct confrontation with the real, trying to transform it, and social knowledge is produced collectively by social actors deconstructing the role of "expert" normally assigned to (investigator)" (Guerra, 2000, p.75).

The experience of working on the ground can transform personally the investigator, since he is subject to the influences of context (Augé; Colleyn, 2004, p.79). In fact he never leaves indifferent to an experience like this, but rather is enriched by it. In the context of the fieldwork, the way of being and of the people with whom one is interacting.

Informs us and teaches us much more than what our organized and conscious memory can get us thinking. It is reflected in us more than we may think. This is what is called knowledge by familiarisation or by impregnation - a knowledge that touches the conscience, but that is translated into an intimate imprint of knowledge of the scenario of the events taking place around us (Augé; Colleyn, 2004, p.74).

1st phase - Acquaintance with Castro Marim and Cacela Velha through multi-sensorial experience, direct observation, participatory observation and a survey of the place through photographic, video graphic and audio registrations.

This direct observation constitutes a case of participant observation, in so far as it is the result of a process of permanence of the researcher in the location, " ... who attends the largest number of sites as possible in the social context in this study, and has a constant presence in the greatest number of activities possible that occur there, being in a permanent conversation with people that belong there ... " (Costa, 1986, p.137).

2nd phase - Direct observation, interaction with residents and efforts to promote their interest in the projects.

I tried to obtain my intentions, by explaining that I would like to put together a project that honoured the people whose lives have depended on the local natural resources. In the first project several times I talked with local people and especially with salt producers about their life experiences.

Later, after having opted for geometric shapes to build large pieces, tests were carried out to observe the behaviour and resistance of salt, since the researcher was not aware of any examples of objects with these characteristics, except with the use of the salt piled in bulk. Therefore, it is through the direct observation of the materials used in the activity of salt farming, of the way the mountains of salt were executed, that resulted in prismatic forms, and their resistance, from which the researcher could extrapolate knowledge and adapt them to the construction of the parts that would constitute the tests (Fig.2-3).

Concerning the second project, the involvement of local people was encouraged. Several meetings with fishermen and bivalve harvesters took place.

The way in which these people built their places of work are demonstrations of sustainable living - an area with great devotion and a very intuitive understanding of the ecological relationship of the human being with the local environment. They fuelled the whole creative process. There are audio registrations and footage of these meetings (Fig.4-5).

People were invited to participate. The idea of giving a voice to these people through the presentation of their own testimonies - through the records of life stories and images of the place associated with the local activities mentioned previously. They were asked to choose an object representing a personal connection with Cacela Velha. The majority had selected their own objects they used or had used in their work. As the anthropologist Adolfo Casal (1997, p.103) says, "the biographical report is not just the account of a life, but the report of a social interaction that made possible this report, which it also became a part of". 

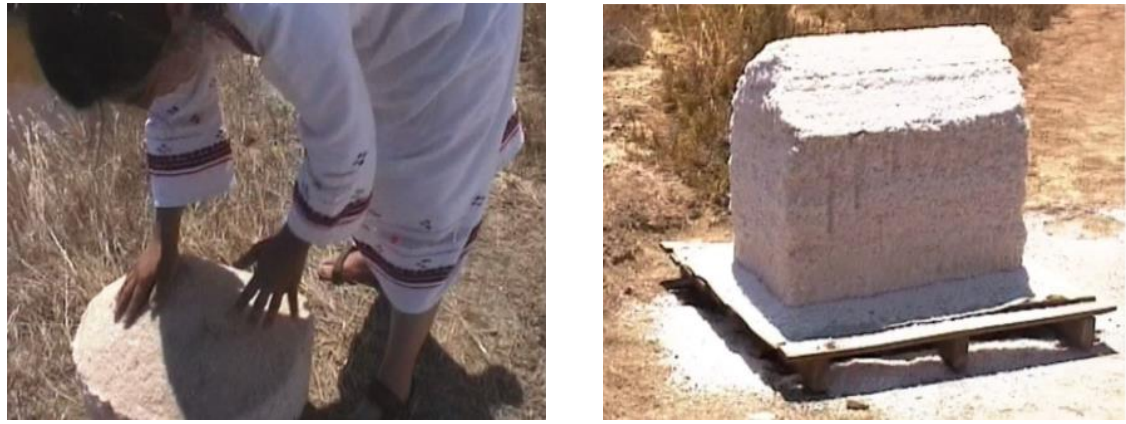

Fig. 2-3: Salt objects resulting from basket mould and wood formwork (Reaes Pinto, 2013).
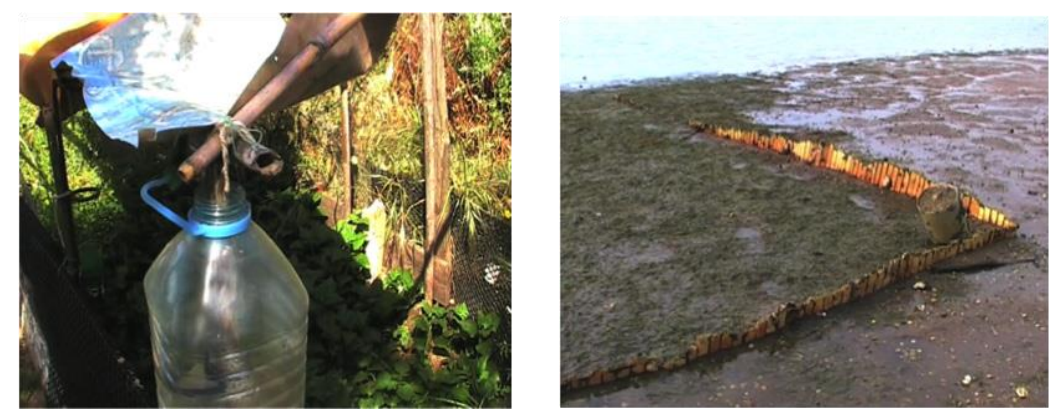

Fig. 4-5: Integrated place (Reaes Pinto, 2013).

3rd phase - Construction of the final pieces. In the first project sculptures were made with the collaboration of artisans, children and local people (Fig.6-7)

The formal character of the sculptures in salt resulted from interaction with the place, understood in an integrated way - the relationship with the landscape, the memory of habits and pre-local stocks (windmills and tidal mills), the topography of the place (Venta Mills), the interaction with the local people, the level of stories told by salt farmers, craftsmen, by officials of the Nature Reserve of the Castro Marim and Vila Real de Santo Antonio and the community in general, by written sources on the salt, by the understanding of the activity of salt farming and its relationship with Castro Marim. Then it was a work of intertwining relations.

In the second project the recording of people's life stories and the photos of their objects were completed. All of these were examples of participatory design. These tasks required meetings with each one of the nine local participants.

There was also carried out a video-animation with the local children in order to raise awareness of the richness of the environment where they live, to gain the respect and mutual learning between the two generations concerned, and to awaken the younger generations to the understanding of creativity as a means of knowledge.

According with the relational practices, the artistic objects produced in both projects did not result from a prior design, by approaching each one of those places in a self-referential and self-contained way, but instead from the interaction with the people and their relationship with the places where they live and work.
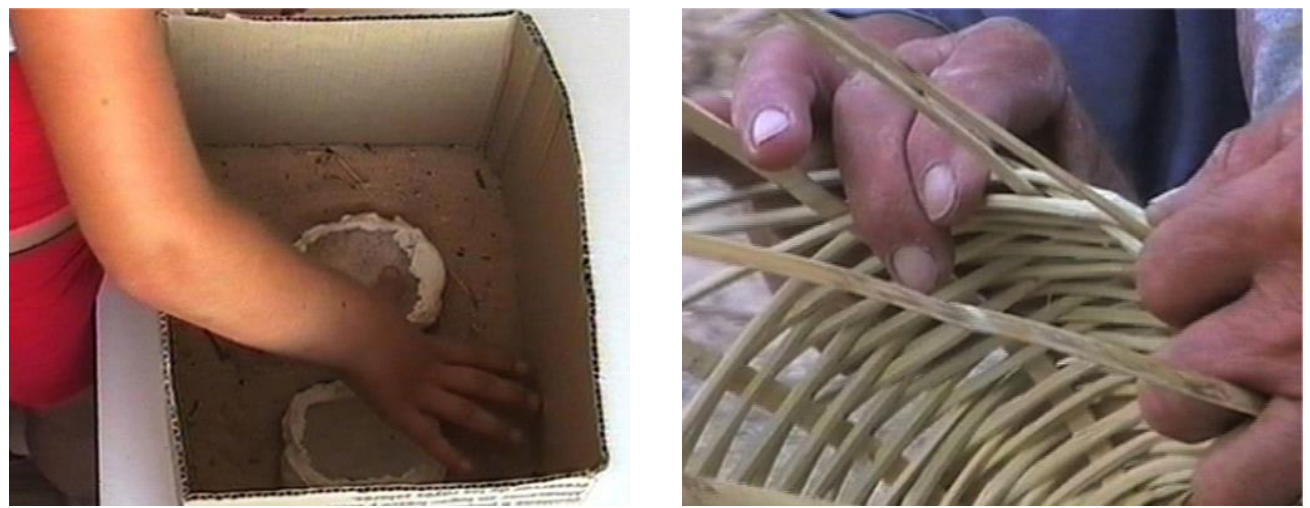

Fig. 6-7: Mould filling with salt by children and craftsman constructing one sculpture (Reaes Pinto, 2013). 
4th phase - Installation exhibition period.

In relation to Paths of Salt, this stage culminated in a tribute to salt farmers and local artisans. It was performed during the opening of the exhibition, in the local chapel, through a symbolic act - the delivery of the "bread of salt", by the local children, to the referred people. In the following year there was a second integrated approach to place, which consisted in the replacement of the salt on the stilt structures of the preceding sculptures. This was done by a group of locals.

The pieces built in salt had completed the life cycle of their material and, therefore, were subject to constraints of local weather, and began their process of fading with the first rains (Fig.8-15). $\square$

In the second project, besides the video-installation that included the audio recordings and accounts of local fishermen regarding their labour activities, nine photos in light boxes were exhibited at the same spot. Each photo represented an object selected by each of the residents. The distinguishing aspect of each object was the stories behind them, narrated by their owners. The narrations could be listened to through headphones located on either sides (Fig.16-20).

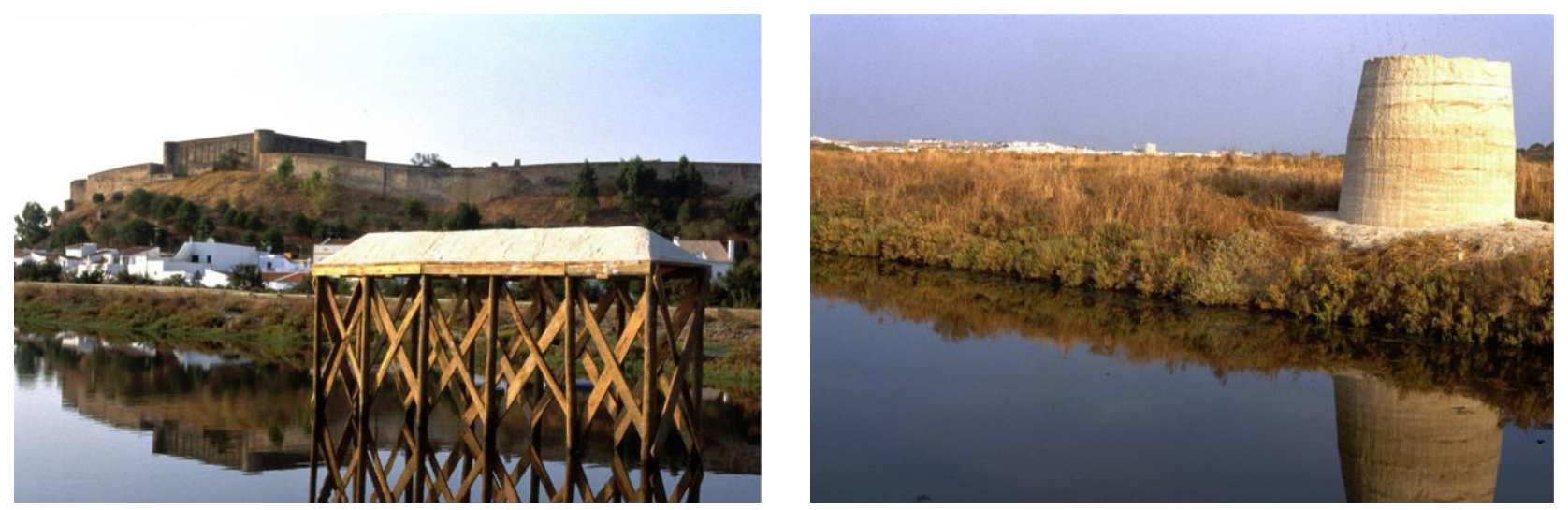

Fig. 8-9: Baracha and Windmills (Reaes Pinto, 2013).
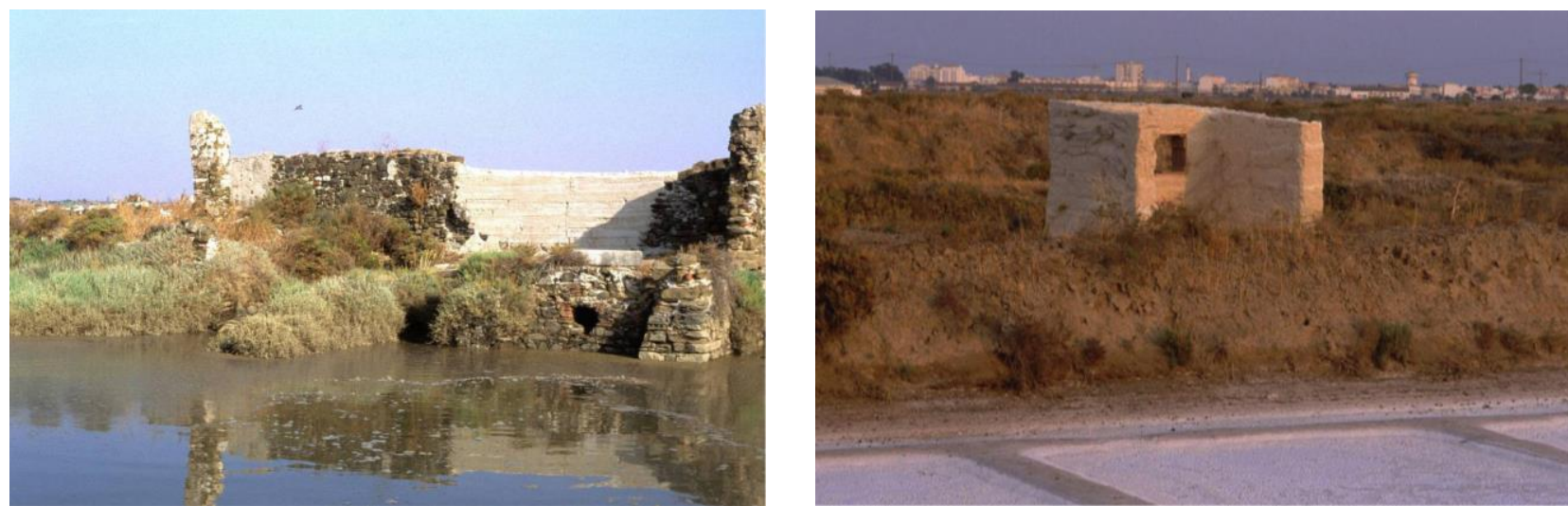

Fig. 12-13: Tidal Mill and Home (Reaes Pinto, 2013). 

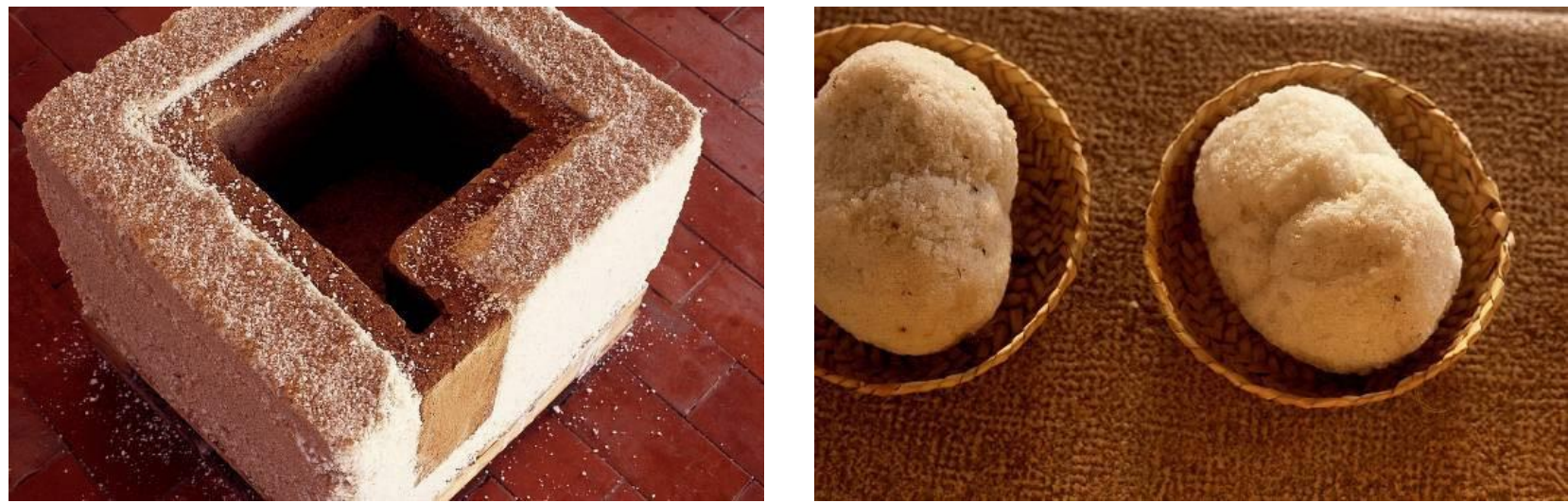

Fig. 10-11. Salt House and Salt Breads (Reaes Pinto, 2013).
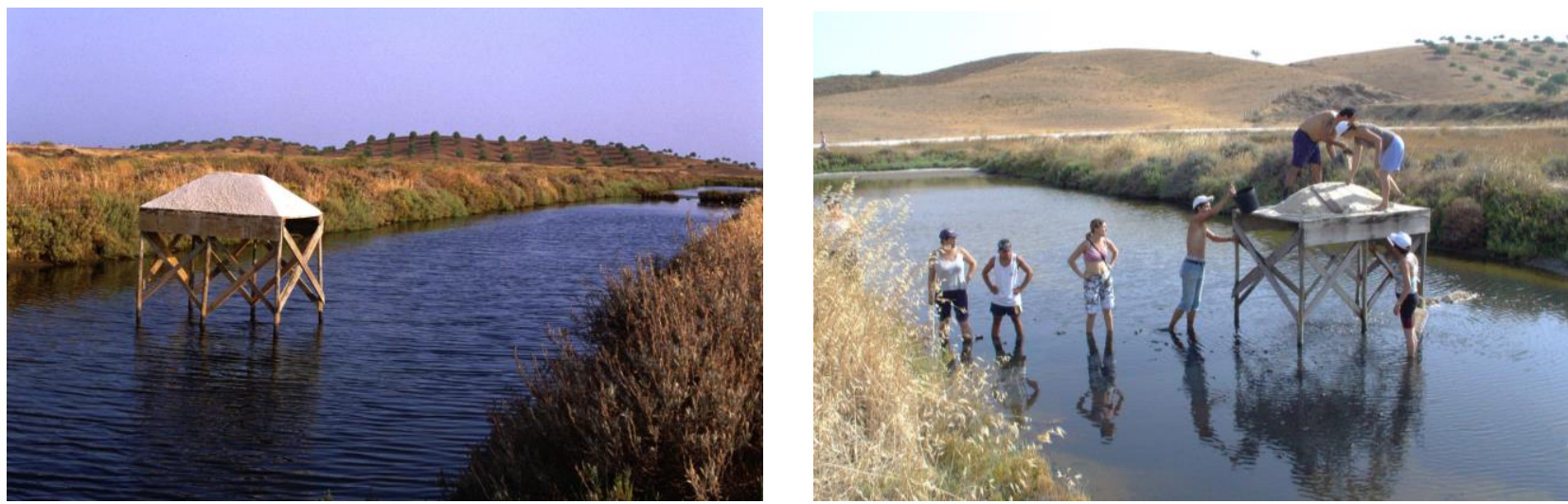

Fig. 14-15: Salt Mountain - second participatory approach (Reaes Pinto, 2013).
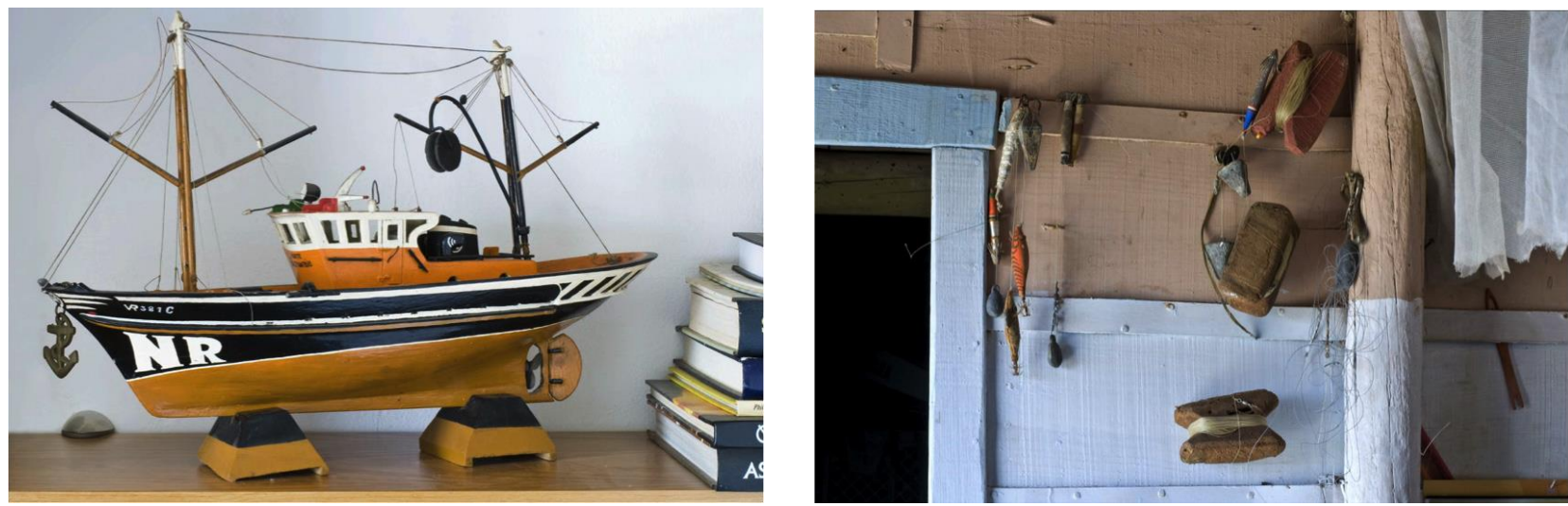

Fig. 16-17: Heitor and Damião (Reaes Pinto, 2013).
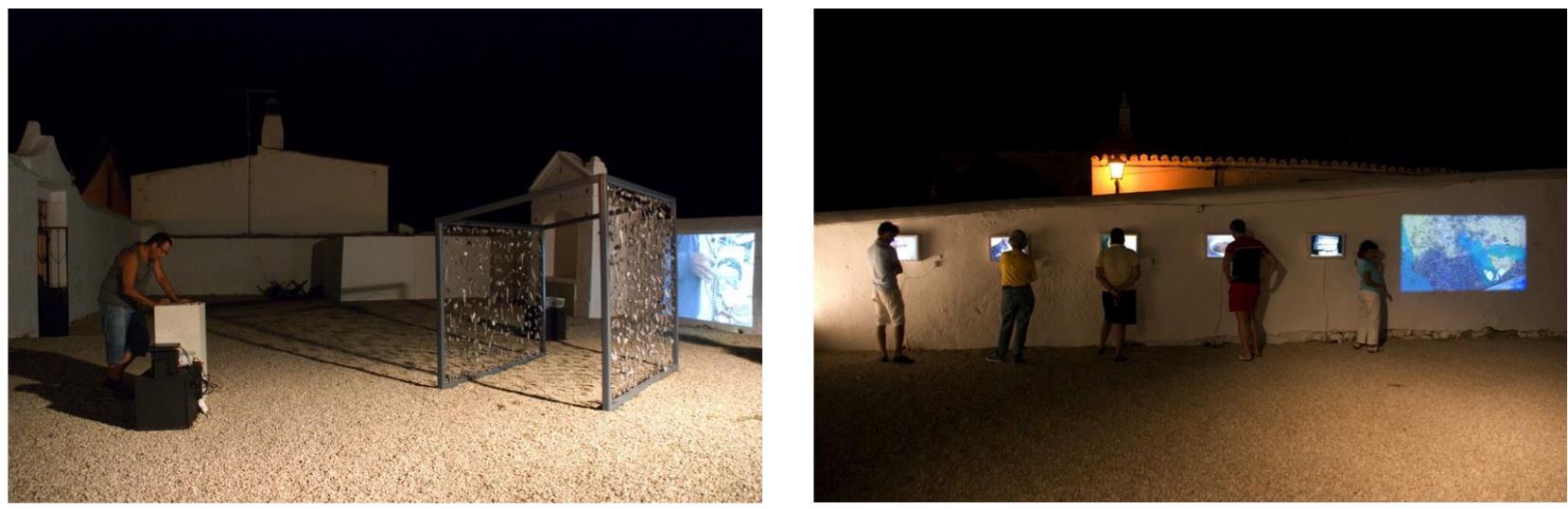

Fig. 18-19: Art exhibition in Cacela Velha (Reaes Pinto, 2013). 

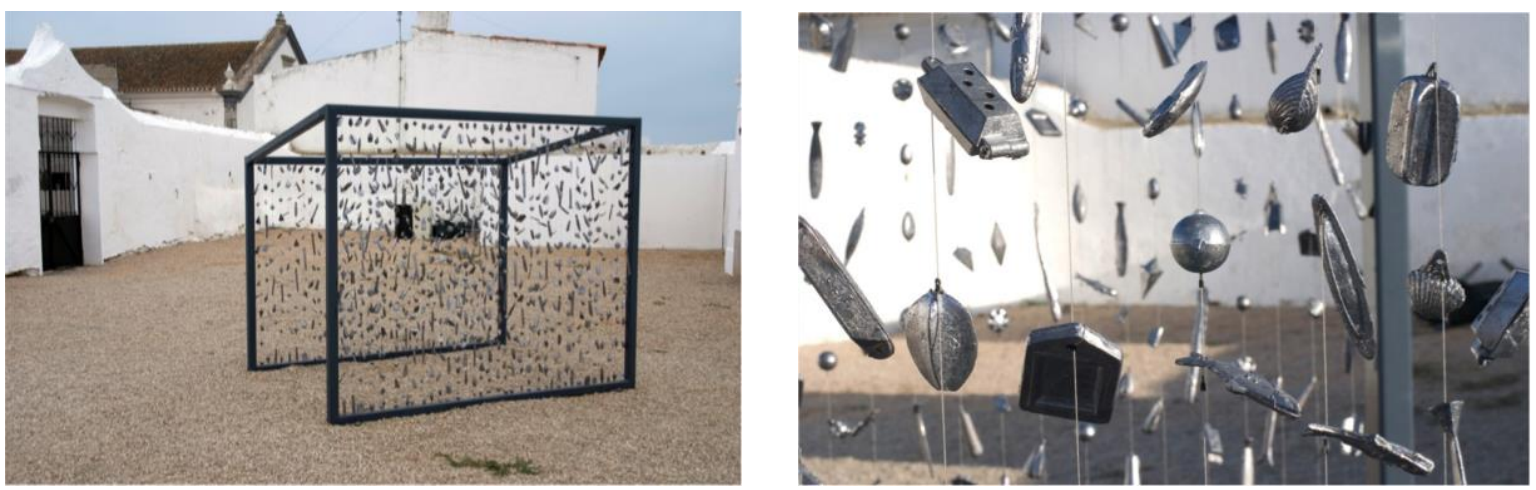

Fig. 20-21: Shelter. Art exhibition in Cacela Velha (Reaes Pinto, 2013).

To clarify and summarise how my concept of place expanded to be, materialized under this project, I can say that the latter was processed at various levels: the conceptual level, by means of an integrated view of the place, which was understood in its various dimensions of human, social, political, cultural, historical, biophysical, geographical, ecological, and at the level of field work, which meant the integration of the artist in the place, which was realized in three sections:

- The knowledge of the place through the experience multi-sensory artist;

- Direct observation, which assumed the presence of artist in place, with the objective to understand the dynamics that relate to the focus of interest of research - the relationship of work activities with the sea and the estuary, which are expressed in the territory and, consequently, in the landscape.

Observations were made of people exercising their activity, in particular, their relationship with the territory, the materials used and their resistance, the instruments and the construction of some of them used in those activities, as well as small support buildings to work activities, built by some of its protagonists on the sandy waterway of Ria Formosa. The impact that these activities have on territory was also noted, taking into account also the interactions established between people. The entire dynamic of the village was also perceived - the homes and the people who lived in them, the cafés, the restaurants, the church and the routines of the focus group and the remaining local population; $\square$

- The participating observation involved interaction with the local population, in particular, the people who were exercising those local activities with the objective of getting to know their social reality and actively involving them in the project and giving them a voice. This approach was based on the paradigm of listening to these people, talking to them, and also using interviews and questionnaires, in order to test the impact that this typology of artistic practice had on this population. The objective was to increase my integration from the perspective with others through the "perspective" of the place, i.e. by integrating myself in an expanded perspective, which includes the other in the relationship between their labour and the environment - in an integrated view of place.

\section{EVALUATION OF THE PROJECT}

The Artistic Interactions with Cacela Velha project is a monitored case-study, whose results were evaluated at three levels: by a panel of experts focused on the theme of the investigation: An art gallery director, USA; an artist, USA; an artist, GB; a designer, POR; a member of the Association for the Rehabilitation and Research of the Natural and Cultural Patrimony of Cacela Velha, POR, by a focus group of local people, and by the population in general visiting the art installation. The experts were interviewed through a previous questionnaire. The focus group was confronted with a semi-structured questionnaire and was interviewed in their habitual whereabouts. The population in general answered a semi-structured questionnaire. During the exhibition there were informative brochures explaining the intentions of the project as well as questionnaires available for general visitors. I often addressed visitors explaining the concept of the project. The contentment of the participants manifested itself in several return visits to the premises of the exhibition and in their comments.

\section{CONCLUSIONS}

The projects were seen by participants and mere observers as conveying a form of art intrinsically connected with the real lives of the people involved and to those factors that give shape to them (human, biophysical, 
geographical, economic, political, social, cultural, historical and ecological); Opposing the exclusive visual paradigm of the western tradition, the art practice in question required multi-sensorial interactions.

The participation of local people in both projects, as well as the valorisation of their life experiences, improved their inclusion in the community and promoted their self-esteem.

The work process resulted also in strong personal bonds and a feeling of complicity between participants and artist.

It should also be noted the inherent richness of inter-and transdisciplinary vision in the methodologies used in active research.

Another important conclusion is to note the leading role of emphatic and participatory approaches used to actively involve people in the realization of artistic projects. Listen and talk to others allowing their perspectives to resonate through the art work in a dignified form means to replace the subjectivity of the artist, typical of conventional modern art, by the intersubjectivity implied in the interaction between artist and participant local people.

The adoption of an integrated view of place promotes sharing life experiences as conditions to put forward a form of public art based on the combined knowledge of all those involved. This community-based public art form reconnects the local population to its labour activities through artist and community interaction in the context of participatory design, using a comprehensive understanding of life experiences with the local population.

\section{ACKNOWLEDGEMENT}

This research was financially supported by: CIAUD - Architecture, Urbanism and Design Research Centre; FCT - Foundation of Science and Technology.

\section{REFERENCE LIST}

Andrews, M. (1999). Land into Landscape. Landscape and Western Art. Oxford: Oxford University Press.

Augé, M. (1998). Dos Lugares aos Não-Lugares. Não-Lugares. Introdução a Uma Antropologia da Sobremodernidade. Venda Nova: Bertrand Editora.

Augé, M. (2004). "O Terreno. Marc Augé, Jean Colleyn”. An Antropologia. Lisboa: Edições 70.

Belenky, Mary; Clinchy, Blythe; Goldberger, Nancy; Tarule, Jill (1996). Women's Way of Knowing. The Development of Self, Voice and Mind. New York: Basic Books.

Bertaux apud Casal (1997). Suportes teóricos e epistemológicos do método biográfico. Trabalho de Campo, Ethnologia, nova série, n 6-8: Lisboa:Edições Cosmos, p. 94

Bohm, D. (1989). “Can Lessons Learned from Subatomic Particles Help Solve Social Problems?”. New Age Journal.

Costa, António Firmino (1986). "A Pesquisa de Terreno em Sociologia. Metodologia das Ciências Sociais". Edições Afrontamento.

Cresswell, T. (2004). Place - A Short Introduction. Oxford: Blackwell Publishing.

Fiumara, G. (1995). The Other Side of Language. A Philosophy of Listening. New York: Routledge.

Guerra, S. (2000). Investigação-Acção - Para Pensar o Mundo Temos de Nos Distanciar ou de Mergulhar Nele? Fundamentos e Processos de Uma Sociologia de Acção. O Planeamento em Ciências Sociais, pp. 53, 75 .

Lacy, S. (1995). "Cultural Pilgrimages and Metaphoric Journeys". Lacy, S. (ed.). Mapping the Terrain. New Genre Public Art, Washington: Bay Press.

Lefebvre, H. (1991). The Production of Space. Oxford: Blackwell Publishers.

Levin, D. (1989). The Listening-Self: Personal Growth, Social Change and the Closure of Metaphysics. Minnesota: Routledge.

Lippard, L. (1995). "Notes from a Recent Arrival". Doherty, C. (ed.) Situation: Documents of Contemporary Art. London: Whitechapel, The MIT Press.

Luke, A. (2009). Design Activism: Beautiful Strangeness for a Sustainable World. London: Earthscan. 